\title{
Investigating suburban environment by means of mental maps: a case study of Olomouc hinterland
}

\author{
Jaroslav Biolek ${ }^{a *}$, Ivan Andráško \\ a Palacký University, Czech Republic \\ b Masaryk University, Czech Republic
}

\begin{abstract}
Suburbanization as a key process transforming the hinterland of cities has been researched by human geographers for a long time. The study of suburbanization involves the application of a wide spectrum of methods or analytic tools falling within the groups of quantitative, qualitative and combined approaches. One of the possibilities to study this process is mental mapping that we primarily use as an instrument for examining the character of suburban environment, its perception by local inhabitants, their experience of and relation to the place of living. The aim of this study is to look at the environment of the suburban municipalities in the hinterland of Olomouc by means of mental mapping. We use concrete examples of sketches to describe and interpret the outputs of perception of the researched suburban municipalities and their components by local inhabitants. Despite schematization, incompleteness or distortion, the results of the study prove that character of their mental maps mostly depends on how much time the inhabitants spend in their municipalities, whether they participate in the collective life or use a map of the municipality and what their relation to place of living is.
\end{abstract}

Key Words: Mental mapping, Suburbanization, Perception of residence, Hinterland of Olomouc, Czech Republic.

Article Info: Received: August 24, 2014; Revised: May 12, 2015; Accepted: May 20, 2015; Online: May 30, 2015.

\section{Introduction}

Suburbanization is mostly characterized as a main process transforming the character of landscape and the shape of municipalities in the hinterland of cities (e.g. Fishman 1989, Harris and Larkham 1999, EEA 2006, Couch et al. 2007). Gottdiener et al. (2006) point out that suburbs, in contrast to cities, are localities

\footnotetext{
* Corresponding author

Address: Department of Geography, Faculty of Science, Palacký University, Olomouc,

Czech Republic.

Email: +420721460656 | jaroslavbiolek@gmail.com
} 
with a lower population density and prevailing residential character. According to Jackson (1985), the suburban sprawl is especially typical of land-use in the USA as an expression of their extensive colonisation and spatial expansion. However, the suburbanization has developed not only in the Northern America but from 1960s in Western Europe and from 1990s in Central-Eastern Europe (CEE) as well (see EEA 2006, Couch et al. 2007, Stanilov and Sýkora 2014). Nevertheless, the expansion of suburbs in Europe has been more regulated, less spatially extensive and the suburbs have emerged attached to some earlier built-up areas. Until 90s the development of the suburbanization in CEE countries was state-controlled and suppressed, especially in Czechoslovakia (e.g. Ravbar 1997, Kok 1999, Suditu et al. 2010, Sýkora and Ouředníček 2001, Krisjane and Berzins 2012, Stanilov and Sýkora, 2014). The socio-economic transformation, higher incomes of the middle class with accessible real-estate credits and mortgages enabled a boom of residential suburbanization in the Czech Republic (see Sýkora and Ouředníček 2001). Galčanová and Vacková (2008) also show how deteriorating quality of life in the Czech cities and, on the other hand, attractivity of the suburban hinterland catalysed the suburban development.

The suburbanization process in CEE has been investigated by various geographical research approaches (see EEA 2006, Couch et al. 2007, Suditu et al. 2010, Stanilov and Sýkora 2014, in the Czech Republic see Ouředníček 2013). A statistical analysis of migration or change of land use has been applied to prove dynamic development or spatial distribution of suburbanization (see e.g. Ravbar 1997, Kok 1999, Sýkora and Ouředníček 2001, Krisjane and Berzins 2012, Šveda 2011). For instance, Romportl and Chuman (2013) demonstrated by GIS that in period 1990 - 2006 the suburban built-up area in the Czech Republic increased by about 246 square kilometers. These analyses have been complemented by case studies, investigating aspects of quality of life, spatial behaviour or geographical separation in the suburban municipalities, in which rather mixed-method approaches and qualitative methods (questionnaires, interviews or observations) have been used (see e.g. Puldová and Ouředníček, 2006, Potočný 2006, Biolek and Andráško 2012, Šveda and Šuška 2014). As Galčanová (2013) accentuates the importance of narratives in the production of the social environment of Czech and Slovak suburbs, the suburbanization has changed not only a physical form of the suburban municipalities but also their cognition and perception as well as behaviour of both denizens and new residents. In this way mental maps represent a suitable, though marginalized and sporadically applied (e.g. Johnston 1971) instrument for analysing the character of the suburban environment, its perception and relation to this place of living.

The aim of this study is to look at the suburban environment by means of mental mapping. Firstly we deal with the comprehension and development of mental maps as a research method of the urban environment. Consequently, after specification of the study area and selected methods, the results from our mental mapping investigation of Czech suburbs are presented. Therefore, we describe and discuss the outputs of perception of the researched suburban municipalities and their components by local inhabitants. In conclusion some methodological potentialities as well as drawbacks of such approach in the suburban environment are outlined. 


\section{Mental mapping in the research on urban environment}

The method of mental mapping has been one of the fundamental human geographical practices. Johnston (1971) argues that, in spite of all the potentialities and possibilities of its application, mental maps as a research method have especially long tradition in the investigation of the urban environment. At the beginning of 20th century first researchers such as Trowbridge (1913, in Naništová and Podlucká 1996) focused their research on the spatial behaviour and sense of orientation of urban residents. These pioneering investigations explored some aspects of the urban residents' mapping and their spatial perception (see Downs and Stea 1973, Gould and White 1986). However, instruments and methods of mental mapping were essentially developed as a reaction to depersonalized spatial scientific approach by behavioural and humanistic geographers in 1960s (e.g. Cloke et al. 2004, Daněk 2013).

Although there exists neither comprehensive nor integrating definition of mental mapping, these approaches, concepts and methods are usually related to the understanding of spatial perception and cognition process. In accordance with Knox and Pinch (2010, p. 225),

\footnotetext{
“(...) cognition and perception are associated with images, inner representations, mental maps and schemata that are result of processes in which personal experiences and values are used to filter the barrage of environmental stimuli to which brain is subjected, allowing the mind to work with a partial, simplified (and often distorted) version of reality".
}

In these circumstances mental mapping is a complex process starting with sensual perception of the place, its transformation and keeping in synaptic structures of the brain and ending with the translation of images of that place into a schematic graphic or cartographic record (Billinge 1986). Therefore, mental map is not considered to be just a translation of a place from memory to paper but rather a complex phenomenon of acquiring, coding, keeping, renewing and decoding of information about localization and attributes of the phenomena in the environment (Stokols 1978).

It is necessary to stress that process of mental mapping can be grasped at two levels. Firstly as a complex psychological process of a person by means of which she or he perceives the space around, gets to know the places and reacts with the surrounding environment and secondly as a scientific investigation of this interaction. We can also understand the mental map both in terms of mental representation of spatial reality and in the form of a graphical output of a scientific method (map, picture, scheme, sketch etc.). Mental maps thus represent geographical instrument through which we obtain various information about a person, her or his spatial perception, knowledge and behaviour and also characteristics of places where this person lives and to which she or he has a certain emotional relation (see e.g. Downs and Stea 1973, Tuan 1975, Gould and White 1986, Golledge and Stimson 1997, Siwek 2011) as we illustrate below.

The key breakthrough in mental mapping occurred with Lynch's concept of imageability applied in the research on cities. Kevin Lynch (1960) paid a significant attention to visual attributes of the urban environment and their legibility and understandability for city inhabitants. Using sketch maps and verbal description of 
places in the cities he developed a methodology how to study the perception of urban environment and also a classification system of urban elements (paths, edges, districts, nodes and landmarks). Although this kind of geographical analysis and description has been criticized, for instance for its intuitive approach to the identification of image elements, it has been broadly used for the interpretation of visual, aesthetic and functional properties of places not only in the cities (Knox and Pinch 2010).

Three dominant ways of perception in the interaction between person and environment were distinguished by Donald Appleyard (1973). Operative perception of elements is based on active, performative actions of people and the use of city, while responsive perception is more 'passive' form of perception. It does not only react to visual stimuli but also to sounds, smells and other forms of tactile experience in urban environment. The third form is inferential perception influenced by a generalized system of environmental categories, concepts and relations that we consciously code during the recognition of the city. These forms of perception are projected into graphic outputs of mental maps by appearance and localization of some features, or by way of drawing. Beside this comprehension, Downs and Stea (1973) focused more on cognitive aspects affecting the character of mental maps. In their opinion, mental mapping is characterised by a selective cognitive process during the depiction of mental representation of the researched environment. They came to the conclusion that mental maps are characterized by their incompleteness, distortion, schematization and augmentation as we prove by examples of researched mental maps.

While these approaches dealt with the designative aspects of the urban environment and its research, humanistic geography has been more oriented on the relation of a person to the urban environment and its appraisal (see Knox and Pinch 2010). In that conception mental mapping has been inspired by phenomenological scientific approach and its aim has been to understand the meanings of spatial elements (e.g. the emotional sense of place) that people attribute to them. Rather than a map, the output of mental mapping is a schema of places a person comes into contact with and to which he or she builds a certain relationship (Tuan 1975). The outputs of studies in the field of humanistic geography also outlined the importance of psychogeographical aspects such as territoriality, stigmatization, emotional relationship to home place or gender and other specific social group patterns and peculiarities (e.g. Ley 1974, Tuan 1974, McDowell 1992).

The cultural turn in geography of 1990s and criticism of the humanistic geography conception opened a space for other feminist, post-structuralist and psychogeographical approaches in mental mapping (see Cloke et al. 2004). These debates also revived thinking about the character of mental mapping process and representation of perceived space (see Mulíček, Osman and Seidenglanz 2013). Although some investigations have continued in the tradition of mental, behavioural or humanistic geography (e.g. Ciobanu 2008, Vacková, Galčanová and Osman 2011), there have appeared new perspectives of participatory action or artbased research (see Pinder 2005, Hawkins 2011, Biolek and Andráško 2013). Mental mapping methods have been also influenced by situationist practice of the performative walking through the city as Hancox (2012) illustrated. To conclude this chapter, all the above mentioned urban research approaches serve us as a guide or perspectives for mental mapping research on the suburban environment. 


\section{Study area}

The municipalities Hlušovice, Dolany, Křelov-Břuchotín and Velký Týnec are located in the hinterland of Moravian regional centre Olomouc, in the eastern part of the Czech Republic (Figure 1). They were chosen on the basis of results of the previous quantitative research and pre-research observation. As you can see in the Tabele 1, these municipalities from Olomouc District (AD MEP Olomouc) show the highest net migration rate as well as index of population growth. However, the preresearch showed that previous place of residence of newcomers is not only Olomouc but also Přerov, Prostějov, Hranice na Moravě or other municipalities in this area (Biolek and Andráško, 2012). They also represent various types of suburban environment with different residential structure and form as well as demographic and socio-economic characteristics.

In Hlušovice, with the highest net migration rate, there live even more newcomers than denizens (living more than 10 years in the municipality). Most houses were built in the form of terraced houses in the new housing estate. Křelov-Břuchotín, the closest municipality to Olomouc, represents the most typical example of suburbanization with new houses around the old built-up area. In Dolany the residential suburbanization started uncontrollably in the middle of 90s, while in Hlušovice and Křelov-Břuchotín at the beginning of the millennium. Dolany and Křelov-Břuchotín could only regulate the building process with great difficulties, because there were no land-use plans at the beginning of the construction. In both municipalities there are usually single-family detached houses with high fences. In most cases the sale of building plots and subsequent construction were initiated by the owners of the plots and by the builders and the construction works were not

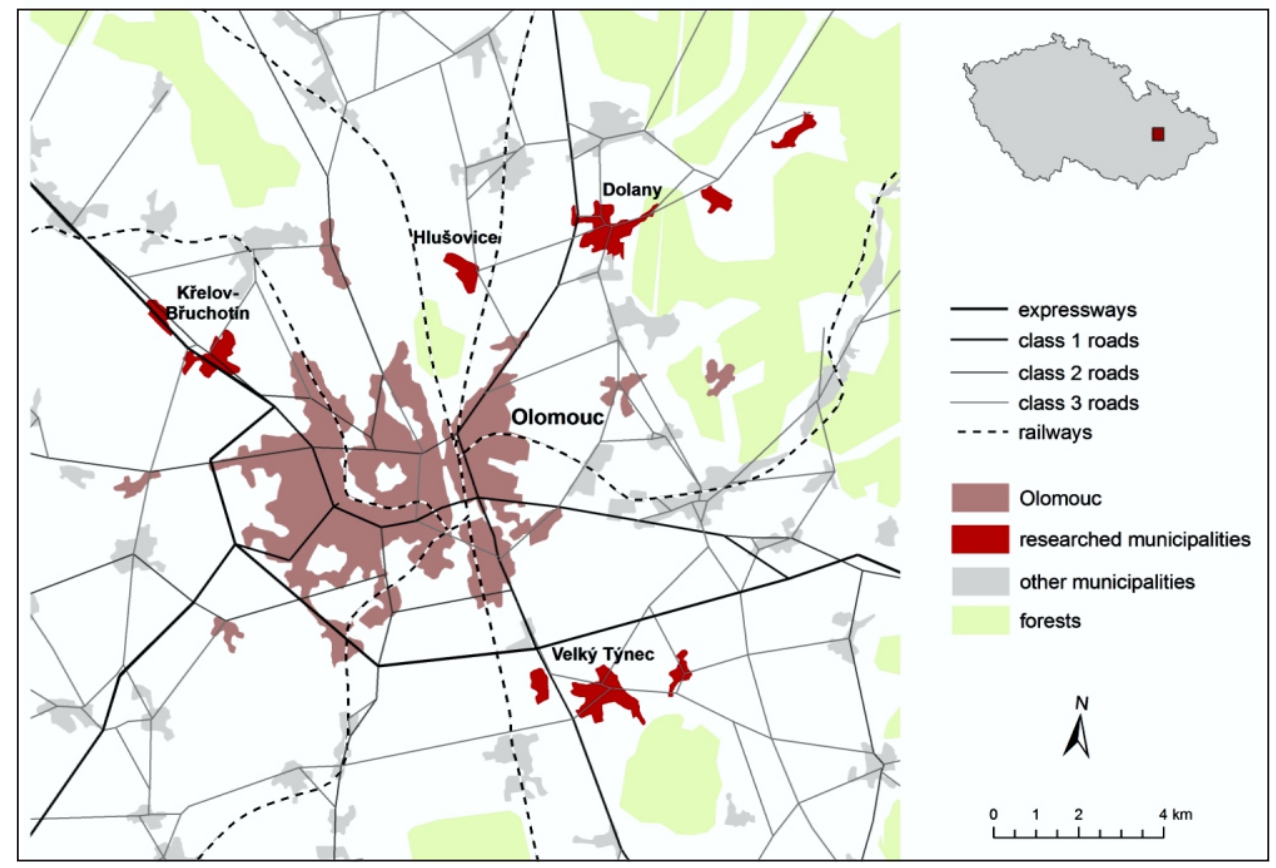

Figure 1. Location of the researched municipalities (source: authors) 
Table 1. Change of population and net migration in the municipalities of Olomouc District (2003-2012)

\begin{tabular}{|c|c|c|c|c|c|c|c|c|}
\hline \multirow[t]{2}{*}{ Municipality } & \multirow[t]{2}{*}{$\begin{array}{l}\text { Population } \\
31 / 12 / 2012\end{array}$} & \multirow{2}{*}{$\begin{array}{l}\text { Index of } \\
\text { population } \\
\text { growth* }\end{array}$} & \multicolumn{3}{|c|}{ Total net migration } & \multicolumn{3}{|c|}{$\begin{array}{l}\text { Net migration rate } \\
\text { per } 100 \text { inhabitants }\end{array}$} \\
\hline & & & $\begin{array}{l}2003- \\
2007\end{array}$ & $\begin{array}{l}2008- \\
2012 \\
\end{array}$ & $\begin{array}{l}2003- \\
2012\end{array}$ & $\begin{array}{l}2003- \\
2007\end{array}$ & $\begin{array}{l}2008- \\
2012 \\
\end{array}$ & $\begin{array}{l}2003 \\
2012 \\
\end{array}$ \\
\hline Hlušovice & 800 & 216,8 & 197 & 189 & 386 & 86,4 & 51,1 & 64,5 \\
\hline Bystrovany & 1030 & 141,3 & 128 & 97 & 225 & 31,8 & 19,6 & 25,1 \\
\hline Bukovany & 610 & 139,6 & 122 & 48 & 170 & 49,3 & 16,3 & 31,4 \\
\hline Hn votín & 1672 & 139,2 & 170 & 262 & 432 & 26,6 & 34,4 & 30,9 \\
\hline Velký Týnec & 2749 & 127,9 & 140 & 394 & 534 & 12,7 & 31,0 & 22,5 \\
\hline Bystrocice & 729 & 123,1 & 46 & 82 & 128 & 15,1 & 23,3 & 19,5 \\
\hline Dolany & 2593 & 119,9 & 299 & 165 & 464 & 26,2 & 13,0 & 19,3 \\
\hline Velký Újezd & 1253 & 117,3 & 113 & 64 & 177 & 20,4 & 10,2 & 15,0 \\
\hline Samotišky & 1323 & 116,4 & 103 & 42 & 145 & 17,3 & 6,5 & 11,7 \\
\hline $\begin{array}{l}\text { K elov- } \\
\text { B uchotín }\end{array}$ & 1636 & 116,2 & 90 & 132 & 222 & 12,5 & 16,8 & 14,8 \\
\hline $\begin{array}{l}\text { B lkovice- } \\
\text { Laš any }\end{array}$ & 2176 & 114,0 & 94 & 123 & 217 & 9,5 & 11,6 & 10,6 \\
\hline Tové & 581 & 113,7 & 72 & 10 & 82 & 26,8 & 3,5 & 14,8 \\
\hline Ústín & 400 & 113,3 & 10 & 13 & 23 & 5,5 & 6,7 & 6,1 \\
\hline $\begin{array}{l}\text { Horka nad } \\
\text { Moravou }\end{array}$ & 2342 & 111,5 & 121 & 35 & 156 & 11,2 & 3,1 & 7,0 \\
\hline Skrbe & 1203 & 111,3 & 102 & 20 & 122 & 18,2 & 3,4 & 10,6 \\
\hline Charváty & 855 & 111,2 & 68 & 8 & 76 & 16,9 & 1,9 & 9,2 \\
\hline Mrsklesy & 619 & 111,1 & 17 & 31 & 48 & 6,0 & 10,5 & 8,3 \\
\hline T łetice & 1337 & 110,3 & 55 & 62 & 117 & 8,9 & 9,5 & 9,2 \\
\hline Suchonice & 178 & 109,9 & 8 & 0 & 8 & 9,5 & 0,0 & 4,7 \\
\hline Doloplazy & 1356 & 109,8 & 40 & 33 & 73 & 6,3 & 5,0 & 5,6 \\
\hline Lub nice & 449 & 109,0 & -5 & 30 & 25 & $-2,5$ & 14,0 & 6,0 \\
\hline Majetín & 1179 & 108,5 & 41 & 76 & 117 & 7,5 & 13,4 & 10,5 \\
\hline Svésedlice & 186 & 108,1 & 5 & 6 & 11 & 5,8 & 6,5 & 6,2 \\
\hline $\begin{array}{l}\text { Nám ł na } \\
\text { Hané }\end{array}$ & 2024 & 108,1 & 138 & 127 & 265 & 14,5 & 12,7 & 13,6 \\
\hline $\mathrm{V}$ rovany & 1409 & 107,9 & 31 & 37 & 68 & 4,7 & 5,4 & 5,0 \\
\hline Blatec & 623 & 107,6 & 18 & 16 & 34 & 6,2 & 5,2 & 5,7 \\
\hline Liboš & 619 & 106,9 & 16 & 31 & 47 & 5,4 & 10,1 & 7,8 \\
\hline Bohu ovice & 2555 & 106,9 & 92 & 37 & 129 & 7,5 & 2,9 & 5,2 \\
\hline $\begin{array}{l}\text { Velká } \\
\text { Byst ice }\end{array}$ & 3099 & 106,4 & 129 & 75 & 204 & 8,8 & 4,9 & 6,9 \\
\hline Grygov & 1469 & 106,1 & 36 & 31 & 67 & 5,2 & 4,3 & 4,7 \\
\hline $\mathrm{P}$ áslavice & 1364 & 105,7 & 37 & 10 & 47 & 5,7 & 1,5 & 3,5 \\
\hline $\begin{array}{l}\text { Dub nad } \\
\text { Moravou }\end{array}$ & 1569 & 105,7 & 80 & -46 & 34 & 10,5 & $-5,9$ & 2,2 \\
\hline Slatinice & 1537 & 105,5 & 47 & 66 & 113 & 6,4 & 8,7 & 7,6 \\
\hline Tršice & 1635 & 104,9 & 37 & 10 & 47 & 4,7 & 1,2 & 2,9 \\
\hline$P$ íkazy & 1267 & 103,5 & 5 & 33 & 38 & 0,8 & 5,4 & 3,1 \\
\hline Št pánov & 3412 & 103,1 & 34 & 23 & 57 & 2,0 & 1,4 & 1,7 \\
\hline Loucany & 641 & 102,7 & 33 & 7 & 40 & 10,4 & 2,2 & 6,3 \\
\hline Krcma & 466 & 102,6 & -3 & 16 & 13 & $-1,3$ & 6,9 & 2,8 \\
\hline $\begin{array}{l}\text { Kožušany- } \\
\text { Tážaly }\end{array}$ & 847 & 102,3 & 10 & -12 & -2 & 2,4 & $-2,8$ & $-0,2$ \\
\hline Lutín & 3249 & 101,7 & -14 & -12 & -26 & $-0,9$ & $-0,7$ & $-0,8$ \\
\hline Daskabát & 587 & 99,7 & 11 & 1 & 12 & 3,7 & 0,3 & 2,0 \\
\hline Drahanovice & 1685 & 99,2 & 8 & 22 & 30 & 0,9 & 2,6 & 1,8 \\
\hline Olomouc & 99471 & 98,2 & -1537 & -1118 & -2655 & $-3,1$ & $-2,2$ & $-2,6$ \\
\hline Hlubocky & 4306 & 96,8 & -62 & -79 & -141 & $-2,8$ & $-3,6$ & $-3,2$ \\
\hline Libavá & 1046 & 86,2 & -62 & -113 & -175 & $-10,5$ & $-20,5$ & $-15,4$ \\
\hline
\end{tabular}

Source: Czech Statistical Office) ${ }^{*} 2003-2012$ (2003 - 100\% 
coordinated. On the contrary, Velký Týnec was affected by suburban development only in last five years and the construction was initiated and mostly regulated by municipality.

\section{Research method}

The mental mapping approach was chosen in order to look at the suburbanization process from the perspective of the local residents and their perception. Our approach is influenced by qualitative and inductive research design, therefore, it gives wider possibilities to informant and it does not set any constraints as what to draw. It does not limit informant's imagination and creativity. On the other hand, it makes the subsequent evaluation and interpretation more difficult because such mental map depicts different spatial elements and dimensions which makes comparison almost impossible. It is also necessary to understand the context in which the informant sketches, what his or her relation to the place is, what his or her drawing abilities are.

The investigation was conducted by trained researchers in August 2012. We did interviews and initiated sketching of mental maps with inhabitants of four municipalities (Hlušovice, Velký Týnec, Křelov-Břuchotín, Dolany). The informants were asked to sketch out the municipality, the place of living and important elements in the spatial context of the municipality. During the creation of mental maps additional questions were asked about the selection of elements and their meaning within their lives, about the character and scale of mental map, perception of socialspatial barriers and other attributes as well as about their age, social status, immigration to their place of living etc. Due to the character of mental mapping research and the willingness of informants to draw, 25 mental maps and related interviews from 4 municipalities were realized. These 25 informants were both denizens and new residents, men and women, youngsters, adults as well as seniors. After the field research the information from the sketches was deciphered, operationalized and sorted. We concentrated on the appeared important elements, the meanings people attributed to them and other associations with their place of living. Finally, they were compared with the results of interviews in the context of informants' characteristics (age, gender, place of living and other social-geographic attributes).

\section{Results and discussion}

The character of mental mapping without strict instructions primarily influenced the formal aspect of created maps, their character or distortion rate and schematization. Table 2 sums up the outputs and key points of the mental maps made by all the informants. There one can find the informant's characteristics, appearance of some significant elements (landmarks), boundaries between old and new built-up districts, way of sketching, distortion rate or other specifics of the mental maps analyzed by the above-mentioned mental mapping approaches. These information are further elaborated on the following paragraphs with an emphasis on the suburban environment and its distinctivity. In Figures 2, 3, 4 there are examples of the mental maps made by informants from suburban municipalities. In these 
Table 2. Informant's characteristics, appearance of the significant elements and boundaries in the mental maps, way of sketching, distortion and other specifics

\begin{tabular}{|c|c|c|c|c|c|c|c|}
\hline \multicolumn{3}{|c|}{ Informant's characteristics } & \multicolumn{2}{|c|}{ Elements in mental maps } & \multicolumn{3}{|c|}{ Character of mental maps } \\
\hline $\begin{array}{c}\text { ID Gende } \\
\text { rage }\end{array}$ & $\begin{array}{l}\text { Place of } \\
\text { living }\end{array}$ & $\begin{array}{l}\text { Denizen } \\
\text { / New } \\
\text { resident }\end{array}$ & Landmarks & $\begin{array}{l}\text { Boundarie } \\
\text { s (number } \\
\text { of districts) }\end{array}$ & $\begin{array}{l}\text { Way of } \\
\text { sketching }\end{array}$ & $\begin{array}{c}\text { Distortio } \\
n\end{array}$ & $\begin{array}{l}\text { Other } \\
\text { specifics }\end{array}$ \\
\hline $1 \quad M 41$ & $\begin{array}{l}\text { Velký } \\
\text { Týnec }\end{array}$ & $\mathrm{N}$ & office & no & $\begin{array}{l}\text { spatial, } \\
\text { schema }\end{array}$ & strong & - \\
\hline 2 F 33 & $\begin{array}{l}\text { Velký } \\
\text { Týnec }\end{array}$ & $\mathrm{N}$ & $\begin{array}{l}\text { office, school, } \\
\text { church, } \\
\text { cinema }\end{array}$ & yes $(2)$ & $\begin{array}{l}\text { sequential, } \\
\text { map }\end{array}$ & low & - \\
\hline $\begin{array}{ll}3 & F 38\end{array}$ & $\begin{array}{l}\text { Velký } \\
\text { Týnec }\end{array}$ & $\mathrm{D}$ & $\begin{array}{c}\text { school, church, } \\
\text { chateau }\end{array}$ & no & $\begin{array}{l}\text { spatial, } \\
\text { picture }\end{array}$ & medium & $\overline{-}$ \\
\hline $\begin{array}{ll}4 & F\end{array}$ & $\begin{array}{l}\text { Velký } \\
\text { Týnec }\end{array}$ & $\mathrm{D}$ & $\begin{array}{l}\text { office, school, } \\
\text { church, shop }\end{array}$ & yes (2) & $\begin{array}{l}\text { sequential, } \\
\text { schema }\end{array}$ & low & - \\
\hline $5 \quad M 55$ & $\begin{array}{l}\text { Velký } \\
\text { Týnec }\end{array}$ & $\mathrm{D}$ & $\begin{array}{l}\text { office, school, } \\
\text { chateau, pitch }\end{array}$ & yes (2) & $\begin{array}{c}\text { sequential, } \\
\text { schema }\end{array}$ & medium & - \\
\hline $6 \quad F 32$ & Dolany & $\mathrm{N}$ & $\begin{array}{c}\text { square, school, } \\
\text { church, } \\
\text { kindergarten }\end{array}$ & no & $\begin{array}{l}\text { spatial, } \\
\text { schema }\end{array}$ & medium & - \\
\hline $7 \quad M 65$ & Dolany & $\mathrm{N}$ & $\begin{array}{l}\text { square, office, } \\
\text { post office, } \\
\text { school }\end{array}$ & yes (2) & spatial, map & low & - \\
\hline $\begin{array}{ll}8 & F 38\end{array}$ & Dolany & $\mathrm{N}$ & - & no & picture & - & $\begin{array}{l}\text { picture of } \\
\text { house }\end{array}$ \\
\hline $9 M 53$ & Dolany & $\mathrm{N}$ & $\begin{array}{l}\text { square, office, } \\
\text { shop, pub }\end{array}$ & no & $\begin{array}{l}\text { sequential, } \\
\text { map }\end{array}$ & low & - \\
\hline $10 \quad M 53$ & Dolany & $\bar{D}$ & $\begin{array}{l}\text { roundabout, } \\
\text { school, pitch, } \\
\text { church }\end{array}$ & yes $(2)$ & $\begin{array}{l}\text { spatial, } \\
\text { schema }\end{array}$ & medium & - \\
\hline 11 F 61 & Dolany & $\bar{D}$ & $\begin{array}{l}\text { roundabout, } \\
\text { church }\end{array}$ & no & $\begin{array}{c}\text { sequential, } \\
\text { schema }\end{array}$ & strong & - \\
\hline 12 F 73 & Dolany & $\mathrm{D}$ & office, church & yes (2) & $\begin{array}{c}\text { sequential, } \\
\text { schema }\end{array}$ & medium & - \\
\hline 13 M 26 & Dolany & $\mathrm{D}$ & $\begin{array}{l}\text { roundabout, } \\
\text { shop, post } \\
\text { office, church }\end{array}$ & yes (2) & $\begin{array}{l}\text { sequential, } \\
\text { map }\end{array}$ & low & - \\
\hline $14 \quad M 48$ & Dolany & $\bar{D}$ & $\begin{array}{c}\text { roundabout, } \\
\text { office, church, } \\
\text { bus stop }\end{array}$ & yes (2) & $\begin{array}{l}\text { sequential, } \\
\text { schema }\end{array}$ & low & - \\
\hline $15 \quad M 48$ & Dolany & $\bar{D}$ & $\begin{array}{l}\text { roundabout, } \\
\text { office, church, } \\
\text { bus stop }\end{array}$ & yes (2) & $\begin{array}{l}\text { sequential, } \\
\text { schema }\end{array}$ & low & - \\
\hline $16 \quad F 33$ & Hlušovice & $\mathrm{N}$ & $\begin{array}{l}\text { office, pub, } \\
\text { culture club, } \\
\text { kindergarten }\end{array}$ & yes (3) & $\begin{array}{l}\text { sequential, } \\
\text { schema }\end{array}$ & low & - \\
\hline 17 M 19 & Hlušovice & $\mathrm{N}$ & $\begin{array}{l}\text { railway station, } \\
\text { pub, pitch, } \\
\text { church }\end{array}$ & no & $\begin{array}{l}\text { spatial, } \\
\text { picture }\end{array}$ & medium & - \\
\hline $\begin{array}{ll}18 & F 50\end{array}$ & Hlušovice & $\mathrm{N}$ & railway station & no & $\begin{array}{c}\text { sequential, } \\
\text { schema }\end{array}$ & medium & - \\
\hline $19 \quad F 12$ & Hlušovice & $\mathrm{N}$ & kindergarten & no & picture & - & $\begin{array}{c}\text { picture of } \\
\text { house and } \\
\text { kindergarten }\end{array}$ \\
\hline 20 F 71 & Hlušovice & $\bar{D}$ & $\begin{array}{l}\text { railway station, } \\
\text { church, shop }\end{array}$ & yes (2) & $\begin{array}{c}\text { sequential, } \\
\text { schema }\end{array}$ & low & - \\
\hline $21 \quad M 69$ & Hlušovice & $\mathrm{D}$ & $\begin{array}{c}\text { railway station, } \\
\text { office }\end{array}$ & yes (2) & $\begin{array}{c}\text { sequential, } \\
\text { schema }\end{array}$ & medium & - \\
\hline 22 F 44 & $\begin{array}{l}\text { K elov- } \\
\text { B uchotín }\end{array}$ & $\mathrm{N}$ & $\begin{array}{l}\text { school, shop, } \\
\text { church }\end{array}$ & yes $(2)$ & $\begin{array}{l}\text { sequential, } \\
\text { schema }\end{array}$ & medium & - \\
\hline 23 F 29 & $\begin{array}{l}\text { K elov - } \\
\text { B uchotín }\end{array}$ & $\mathrm{N}$ & - & yes (2) & schema & - & two circles \\
\hline $24 M 46$ & $\begin{array}{l}\text { K elov- } \\
\text { B uchotín }\end{array}$ & $\bar{D}$ & $\begin{array}{l}\text { office, church, } \\
\text { pub }\end{array}$ & yes (3) & $\begin{array}{l}\text { spatial, } \\
\text { schema }\end{array}$ & low & - \\
\hline $25 \quad M 56$ & $\begin{array}{l}\text { K elov - } \\
\text { B uchotín }\end{array}$ & $\bar{D}$ & $\begin{array}{l}\text { office, church, } \\
\text { school, pitch }\end{array}$ & no & $\begin{array}{l}\text { sequential, } \\
\text { schema }\end{array}$ & medium & - \\
\hline
\end{tabular}




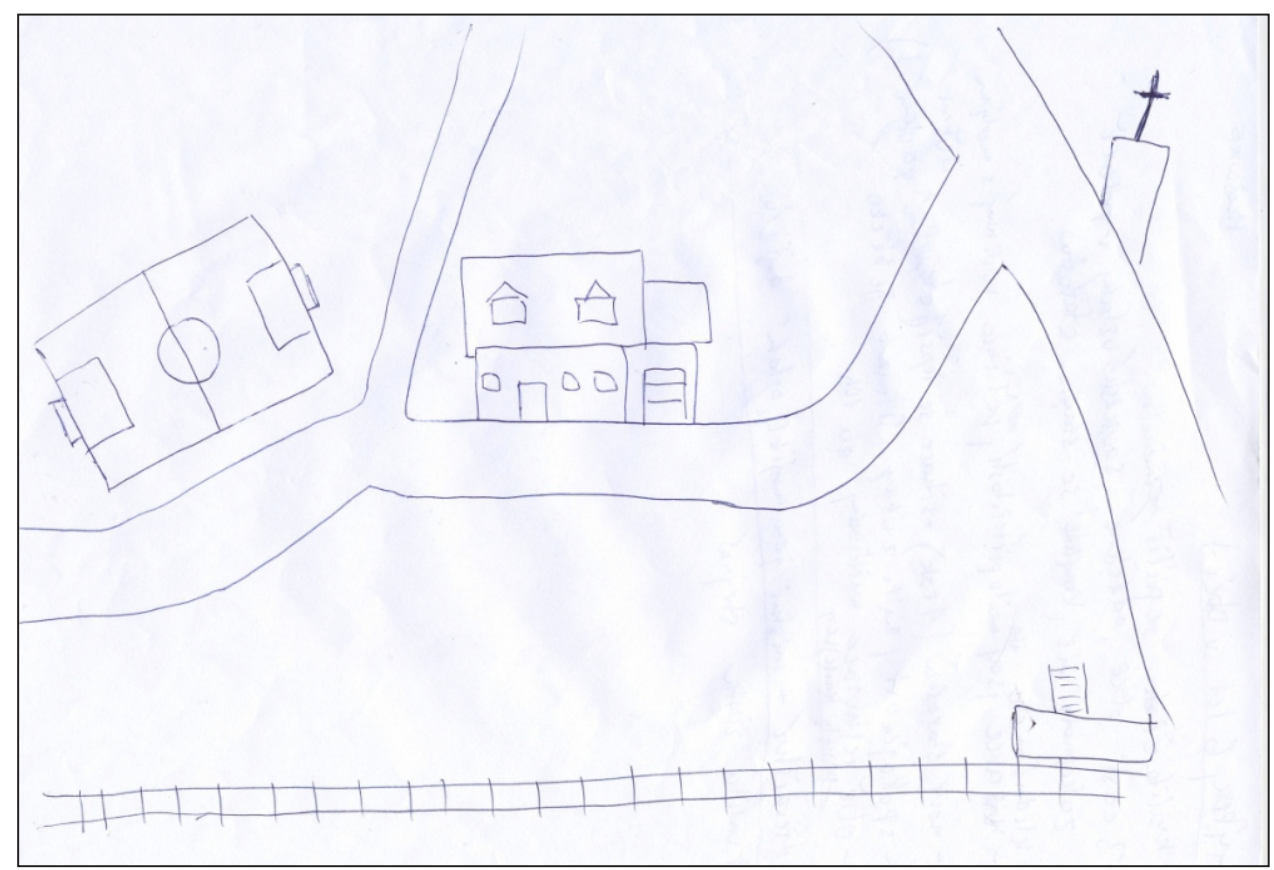

Figure 2. Mental map made by a 19-year-old man, newcomer from Hlušovice

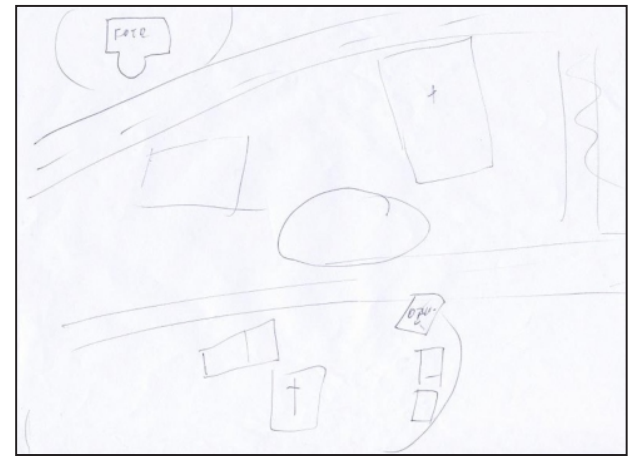

Figure 3. Mental map made by a 46-yearold man, denizen from Krelov-Bruchotín

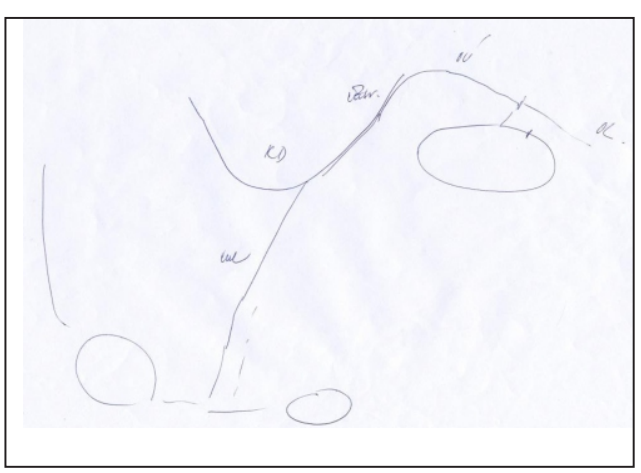

Figure 4. Mental map made by 33-yearold woman, newcomer from Hlušovice

figures we can demonstrate the results and crucial findings as well. Firstly, we may observe different types of illustration on the scale from pictures and sketches through schemas and descriptions up to maps and plans. While some informants approached to mental mapping as plain drawing and they drew their house, railway station or a pub as realistically as possible, not respecting the scale much (Figure 2), others tried to include all the important elements paying attention to the spatial context (Figure 3), but mostly only as points with descriptions (Figure 4). Thus, most of the informants sketched the components in the mental maps either in the form of schemas or they simply marked them by writing, just because they did not want to spend more time drawing.

Nevertheless, most of the analysed mental maps include similar elements of infrastructure and public facilities. Informants from all the municipalities, both denizens and new immigrants, mostly depicted their houses, municipal office, church, pub, shop, football pitch, bus stop, post office or kindergarten, and 
eventually primary school (in Dolany and Velký Týnec), roundabout or square (in Dolany), railway station (in Hlušovice), or chateau and cinema (in Velký Týnec). According to Lynch's conception (1960), these components are dominants which make the suburban space more legible for the local inhabitants and contribute to produce the "image" of the suburban municipality. The partial elements of the mental maps are then connected by paths - roads that served to the informants as a means of navigation owing to which they were able to localise point elements in the map. There are some important nodes (like roundabout in Dolany) that help people to orientate themselves in the process of sketching mental map too.

The creation of the mental maps usually began in the middle of the municipality (e.g. starting with the village square, municipal office building, church or roundabout) or from their own house and then it was further drawn along the roads. According to Appleyard (1973) that was sequential mental mapping rather than spatial, however, with an emphasis on positional placing of important elements. Thus, after the first picture or schema of their house or landmark in the centre of suburban municipality, the informants usually sketched the roads and then localized the other important spatial components into the mental maps. As regards the importance of depicted elements in the eyes of local inhabitants, the outputs of the additional questions show the informants perceive the elements of infrastructure and public facilities of the municipality to be important for their everyday lives. Although, according to interviews, they do not often go shopping in the local shop or they do not use local railway station to go by train, these elements play an important role in the spatial orientation. However, there are some elements or areas in the mental maps which function as both navigation points as well as community interaction fields where the people really meet with each other such as the village square (see e.g. Galčanová and Vacková 2008).

By comparing the sketches to real maps of the municipalities we can also prove that informants, both denizens and new residents, are well acquainted with the space in their municipality and with its landmarks. Although these mental maps are distorted and incomplete (see Downs and Stea 1973), they show solid geographical knowledge and spatial orientation of the informants. The informants had the biggest problem with the accuracy of distances and scale, especially in the larger municipalities. In total 25 mental maps there are only a few specific cases which show insufficient spatial knowledge of newcomers. On the contrary, in some cases (e.g. in Hlušovice) the new residents knew the spatial disposition of the whole municipality even better than the denizens, because of their lack of interest to visit new neighbourhoods that only have residential function. The outputs also proved there is no statistically significant difference in the way of perception and sketching of mental maps according to gender, age, or social status. There are only a few cases of differences in which, for instance, some women depicted kindergartens or clubs for young women and, on the other hand, some men sketched the football pitches which were not located in women's mental maps (e.g. McDowell 1992).

However, some mental maps show anomalies. For example, just a simple picture of a house is the most specific one in which the informant who does not spend time in the municipality suggestively depicted her limited spatial knowledge. It is a typical example of a new resident who spends most of her time in Olomouc and she perceives the municipality only as "a place for sleeping". An opposite example is a map sketched by a representative (Figure 4) who often works 
with land-use plan, so he views the municipality from a wider perspective. According to his answer he also actively participated in the collective life in the municipality. Another 19-year-old man from Hlušovice, even though immigrated there 6 years ago, was integrated in the collective life in the municipality as well. He spent a lot of time in Hlušovice and knew its places very well, because he played football for the local club, as you can see in Figure 2. Therefore, the ability to use the scale properly can be one of the signs of knowledge of this environment and active involvement (operative perception, see Appleyard 1974), however, the character of mental maps can be influenced by the relation to the municipality and place of living (topophilia, see Tuan 1974).

Mental mapping in the selected suburban municipalities put an emphasis on delineation of the barriers between formerly built-up area and new residential neighbourhoods. One of the analysed mental maps specifically concentrates on the spatial relation between the old and new part of the municipality. There is a perception of the suburb surrounding the old built-up area of the municipality. Although other informants often depicted suburb as a specific district of the municipality (especially in Dolany and Křelov-Břuchotín), they did not explicitly speak about spatial separation, however, underlining neither barriers nor boundaries. It means that social-spatial barriers between both parts of suburban municipalities exist but they are not so significant and often artificially created in the eyes of local inhabitants.

The suburbanization process in the hinterland of Olomouc has not been so dynamically developed like in the surroundings of more populated cities (like Prague or Brno hinterland in the Czech Republic). The various socialdemographic and geographic background of new residents also wipes out the differences in the perception of suburbs which can be seen in more typical cases of the residential suburbanisation (with signs of gated communities or another spatial separation). The mental maps also show that most informants perceive their house, place of living or, generally, 'social-geographical environment' as important. They consider suburban municipalities suitable for the upbringing of children and the possibility to spend time outdoors as a relevant factor for their quality of life. Nevertheless, the interpretation of social-spatial dynamics of the suburban municipalities through mental mapping is more difficult. It would be better to evaluate and reflect this process using the same methods after a few years, because then, for instance, we can compare the transformation of the new residents' relationship to their place of living, their sense of orientation etc.

\section{Conclusion}

The primary aim of the article was to look at the suburban environment by means of mental mapping and, secondarily, to present the results from mental maps sketched in suburban municipalities in the hinterland of Olomouc. In order to analyse spatial attributes of the suburban municipalities and to interpret their perception by newcomers and denizens we used a mental mapping approach with unlimited instructions about how to draw a mental map. We also discussed and reflected the researched mental maps through the conceptual approaches of Lynch, Appleyard or Tuan. 
The outputs of this research prove that local inhabitants are usually well acquainted with the space of the municipality and with the localisation of the elements of infrastructure and public facilities. These landmarks also create "image" of the suburban municipality in the eyes of local inhabitants. Slight differences can be seen in the perception of the municipality by denizens and new immigrants. However, even though the new built-up areas were spatially delineated, we cannot speak about geographical separation or social exclusion. It is rather a construct that the inhabitants themselves exaggerate by means of narratives. There were also no significant differences in the mental maps according to informants' age, gender or social status. The character of the mental maps and informants' knowledge of the suburban municipalities and their attributes depends on how much time they spend there, whether they participate in the collective life or use a map of the municipality and, of course, what their relation to place of living is. It is thus possible to read the information from mental maps both about the suburban municipality and its visual, functional and aesthetic properties as well as about the informant himself or herself, about his or her knowledge of the environment and the ability to depict geographical connections and relation to the place of living. Nevertheless, the outputs did not much reflect the social-spatial dynamic of the suburban development which can be evaluated after few years by the same methods.

The researched mental maps are characterized by significant schematization, incompleteness or distortion. On the other hand, the informants are not limited by anything during the creative processes of drawing the mental map and they can freely approach the depiction which unveils a lot of facts that would remain hidden if a different methodology was used. However, we should remind constraints of this approach within which is difficult to exactly explain data. In our opinion such approach, in spite of some methodological drawbacks, offers the potential of development when applied not only in the suburban environment.

\section{Notes}

The research study was funded by the project of the Czech Science Foundation: "Urban and suburban quality of life: a geographical perspective" (P404/11/1811). The authors are grateful for this support.

\section{References}

Andráško, I, Soukalová, L \& Šuška, P 2011, 'Obraz miesta - realitný imidž verzus reálny stav', in I Andráško, V Ira \& E Kallabová (eds), Časovo-priestorové aspekty regionálnych štruktúr $\breve{C} R a$ SR, Geografickýústav SAV, Bratislava, pp. 5-11.

Appleyard, D 1973, 'Notes on urban perception and knowledge', in RM Downs \& D Stea, (eds), Image and environment: Cognitive mapping and spatial behaviour, E. Arnold Publishers, London, pp. 109-114.

Billinge, M 1986, 'Mental Map', in RJ Johnston, DGregory \& DM Smith (eds), The Dictionary of Human Geography, Blackwell, Oxford, pp. 295.

Biolek, J \& Andráško, I 2012, 'Rezidenční suburbanizace v zázemí nejvetších mest Olomouckého kraje', in I Andráško, P Dvorák, \& V Ira (eds), Časoprostorové zmeny 
regionálních struktur $\check{C} R$ a SR. Brno (Ústav geoniky AV ČR), pp. 5-11.

Biolek, J \& Andráško, I 2013, 'Geografie a umení: Site-specific art v akcích Kateriny Šedé', in H Svobodová (ed), Nové výzzy pro geografii: Sborník výročni konference České geografické společnosti, Masarykova univerzita, Brno, pp. 142-151.

Ciobanu, Cr 2008, 'The Mental Map of Neighbourhoods in Bucharest Introductive Study of Mental Geography', Human Geographies - Journal of Studies and Research in Human Geography, vol. 2, no. 1, pp. 25-34.

Cloke, P, Cook, I, Crang, P, Goodwin, M, Painter, J \& Philo C 2004, Practising Human Geography, SAGE Publications, London.

Couch, C, Petschel-Held, G \& Leontidou, L 2007, Urban sprawl in Europe. Landscapes, LandUse Change and Policy, Blackwell Publishing, Oxford.

Danek, P 2013, Geografické myšlení: úvod do teoretických prístupu, Masarykova univerzita, Brno.

Downs, RM \& Stea, D 1973, 'Cognitive mapping and spatial behavior: Process and products', in RM Downs \& D Stea (eds), Image and environment: Cognitive mapping and spatial behavior, E. Arnold Publishing, London, pp. 8-26.

EEA 2006, Urban sprawl in Europe: The ignored challenge, European Environment Agency, Copenhagen.

Fishman, R 1989, Bourgeois Utopias: The Rise and Fall of Suburbia, Basic Books, New York.

Galčanová, L \& Vacková, B 2008, 'Rezidenční suburbanizace v postkomunistické České republice, její koreny, tradice a současnost', IVRIS Papers, vol. 3, no. 2, pp. 1-23.

Galčanová, L 2013, 'Svoboda, soukromí a bezpečí: nové hraniční prostory v naracích obyvatel vybraných brn nských predmestí', in M Ouredníček, P Špačková \& J Novák (eds), Suburbs: Krajina, sídla a lidé, Academia, Praha, pp. 200-233.

Golledge, RG \& Stimson, RJ 1997, Spatial behaviour: a geographic perspective, Guilford Press, New York.

Gould, P \& White, R 1986, Mental Maps, 2nd edn., Routledge, London.

Hancox, S 2012, 'Contemporary Walking Practices and the Situationist International: The Politics of Preambulating the Boundaries Between Art and Life', Contemporary Theatre Review, vol. 22, no. 3, pp. 1-17.

Harris, R \& Larkham, PJ 1999, Changing Suburbs. Foundation, Form and Function, Routledge, London.

Hawkins, H 2011, 'Dialogies and Doings: Sketching the Relationships between Geography and Art', Geograph Compass, vol. 5, no. 7, pp. 464-478.

Jackson, KT 1985, Crabgrass Frontier: The Suburbanization of the United States, Oxford University Press, Oxford.

Johnston RJ, 1971, 'Mental maps of the city: suburban preference patterns', Environment and Planning, vol. 3, no. 1, pp. 63-72.

Knox, P \& Pinch, S 2010, Urban social geography: an introduction, 6th edn, Pearson Education Ltd, London.

Kok, H 1999, 'Migration from the city to the countryside in Hungary and Poland', Geojournal, vol. 49, no. 1, pp. 53-62.

Krisjane Z \& Berzins, M 2012, 'Post-socialist urban trends: new patterns and motivations for migration in the suburban areas of Riga, Latvia', Urban Studies, vol. 49, no. 2, pp. 289-306.

Ley, D 1974, The Black Inner City as a Frontier Post, Association of American Geographers, Washington, DC.

Lynch, K 1960, The image of the city, MIT Press, Cambridge, Mass.

McDowell, L 1992, 'Doing gender: feminisms, feminists and research methods in human geography', Transactions of the Institute of British Geographers, vol. 17, pp. 399-416.

Mulíček, O, Osman, R \& Seidenglanz, D 2013, 'Imaginace a reprezentace prostoru v každodenní zkušenosti', Sociologickýčasopis, vol. 49, no. 5, pp. 781-810.

Naništová, E \& Podlucká, D 1996, 'K problematike mentálnych máp: historický prehlad s dôrazem na humánnu geografiu a environmentálnu psychológiu', Acta Environmentalica Universitatis Comenianae, vol. 6, pp. 35-46. 
Ouredníček, M 2013, 'Výzkum suburbanizace v České republice: současné tendence vývoje a možné aplikace', in M Ouredníček, P Špačková \& J Novák (eds), Suburbs: Krajina, sídla a lidé, Academia, Praha, pp. 61-80.

Pinder, D 2005, 'Arts of human exploration', Cultural Geographies, vol. 12, no. 4, pp. 383-411.

Potočný, T 2006, 'Lidé na okraji. Prípadová studie satelitního mestečka', IVRIS Papers, vol. 1, pp. 1-47.

Puldová, P \& Ouredníček, M 2006, 'Zmeny sociálního prostredí v zázemí Prahy jako dusledek procesu suburbanizace', in M Ouredníček (ed), Sociálni geografie Pražského mestského regionu. Univerzita Karlova v Praze, Prírodovedecká fakulta, Praha, pp. 128-142.

Ravbar, M 1997, 'Slovene Cities and Suburbs in Transformation', Geografski zbornik, vol. 37, pp. 65-109.

Romportl, D \& Chuman, T 2013, 'Zmena krajinného pokryvu a struktury krajiny v České republice vlivem suburbanizace', in M Ouredníček, P Špačková \& J Novák (eds), Sub Urbs: Krajiny, sídla a lidé, Academia, Praha, pp. 102-118.

Siwek, T 2011 , Percepce geografického prostoru, ČGS, Praha.

Stanilov, K \& Sýkora, L (eds.) 2014, Confronting Suburbanization: Urban Decentralization in Postsocialist Central and Eastern Europe, Willey-Blackwell, Oxford.

Stokols, D 1978, 'Environmental psychology', Annual Review of Psychology, vol. 29, pp. 253295.

Suditu, B, Ginavar, A, Muica, A, Iordachescu, C, Vârdol, A \& Ghinea, B 2010, 'Urban sprawl characteristics and typologies in Romania', Human Geographies - Journal of Studies and Research in Human Geography, vol. 4, no. 2, pp. 79-87.

Sýkora, L \& Ouredníček, M 2001, Sprawling post-communist metropolis: commercial and residential suburbanisation in Prague and Brno, the Czech Republic, SELMA, Praha.

Šveda, M 2011, 'Suburbanizácia v zázemí Bratislavy z hladiska analýzy zmien krajinnej pokrývky', Geografickýčasopis, vol. 63, pp. 155-173.

Šveda, M \& Šuška, P 2014, 'K príčinám a dôsledkom živelnej suburbanizácie v zázemí Bratislavy: príklad obce Chorvátsky Grob', Geografickýčasopis, vol. 66, pp. 225-246.

Trowbridge, C 1913, 'On fundamental methods of orientation and imaginary maps', Science, vol. 38, pp. 888-897.

Tuan, YF 1974, Topophilia, Prentice-Hall, Englewood Cliffs, NJ.

Tuan, YF 1975, 'Images and mental maps', Annals of the Association of American Geographers, vol. 65, no. 2, pp. 205-213.

Vacková, B, Galčanová, L \& Osman, R 2011, 'Prostor "pred nádražím"v Brne - perspektiva chodce', Urbanismus a územní rozvoj, vol. 14, no. 5, pp. 17-25. 